\section{Cooperative Learning to Enhance Horticulture Skills and Raise Funds for Professional Development}

\author{
Brian J. Pearson ${ }^{1,4,7}$, Kimberly Moore ${ }^{2,5}$, and James Barrett ${ }^{3,6}$
}

ADDITIONAL INDEX wORDs. international learning, horticulture club

SUMMARY. Increased global trade coupled with diversified employment opportunities have generated demand for college graduates to possess enhanced interpersonal and foreign communication skills and a well-developed understanding of foreign culture. Horticultural employment opportunities also require students to possess a mastery of horticultural theory with an established record of direct, hands-on experience. Despite these needs, financial limitations of students and academic departments coupled with a lack of available opportunities may restrict students from developing these critical skills. Through development of cooperative learning programs, students have an opportunity to master and refine their horticultural skills while simultaneously raising funds, which are allocated for professional development including an international learning program. This article provides a successful overview of a student-based cooperative learning program that enhances student learning opportunities.

$\mathrm{D}$ iverse job markets coupled with increased competition have generated an increased demand for college graduates possessing transferrable proficiencies in critical thinking and communication skills. In addition, ever-increasing interconnected global markets together with international trade, communication, and workplace diversity have created an increased need for graduates possessing a well-developed understanding of foreign culture, language, and communication skills (Acker, 1999). Despite this workplace need, internal and external barriers exist that impede the development of these skills within academic institutions. Barriers include a lack of cultural knowledge and language

This article was part of the workshop "Five-minute Impact Strategies for Engaging Students-Where to Start with Service-learning and Fundraising?" held on 4 Aug. 2015 at the ASHS Annual Conference, New Orleans, LA, and sponsored by the Teaching Methods (TCHG) Working Group

${ }^{1}$ Department of Environmental Horticulture, University of Florida, Mid-Florida Research and Education Center, 2725 S. Binion Road, Apopka, FL 32703

${ }^{2}$ Department of Environmental Horticulture, University of Florida, Ft. Lauderdale Research and Education Center, 3205 College Avenue, Davie, FL 33314

${ }^{3}$ Department of Environmental Horticulture, University of Florida, 1549 Fifield Hall, Gainesville, FL 32611

${ }^{4}$ Assistant Professor

${ }^{5}$ Professor

${ }^{6}$ Professor Emeritus

${ }^{7}$ Corresponding author. E-mail: bpearson@ufl.edu.

doi: 10.21273/HORTTECH03345-17 skills and lack of available opportunities (Briers et al., 2010; Irani et al., 2006; Wingenbach et al., 2006). Moreover, given high costs often associated with international learning and professional development opportunities, students may lack financial resources necessary to engage in available programs (Irani et al., 2006; Smith et al., 2013).

Academic programs have been criticized for failing to develop advanced, hands-on skills in graduates (Campbell, 1998; National Research Council, 2009). Cooperative learning integrates traditional classroom instruction with hands-on, practical work experience and directly addresses this need. Horticultural cooperative learning programs can be designed to provide students with practical work experience in plant production. In turn, plants produced as a result of these programs may be sold to raise funds to offset expenses of professional development opportunities including international study programs. Furthermore, funds raised from cooperative learning programs can be used to support departmental programs and foster enhanced communication and critical thinking skills among students. The objectives of this article are 1 ) describe the benefits of cooperative learning and its ability to foster skill development, 2) discuss the importance of international learning programs, and 3) describe a student-based cooperative learning program that generates funds that support professional development including an international study opportunity.

\section{Cooperative learning}

Cooperative learning was first defined by Wilson and Lyons (1961) as study which integrates classroom and practical work experience. They describe a number of benefits, including enhanced connections between theory and practical applications of knowledge, improvements in selfmotivation due to enhanced perceptions of necessary employment skills, improved sense of responsibility, and enhanced interpersonal communication skills. Additional benefits were described by McKeachie (1994) and Tyler (1981) and include increased student confidence and better clarity of learning goals, and a sense of mutual support and stimulation working with peers. Cooperative learning programs may be implemented in the form of a student organization or club. Karcher and Trottier (2014) reported student club members felt club participation allowed for enhanced understanding of classroom concepts and improved relationships among peers and faculty.

Rowe (2015) advised against adoption of cooperative learning. She felt that it instilled a greater focus on monetary benefits of employment than academic success. Rowe argued that students who elect noncooperative learning opportunities were motivated by more altruistic motives. Although Rowe is justified in her argument, programmatic adjustments can and should be designed to remove or reduce direct economic incentives to students and to promote academic benefits over monetary gain, instead.

Cooperative learning programs have been implemented by a majority of academic institutions. By 1979, $83 \%$ of academic institutions offering agricultural degrees in the United States incorporated a cooperative learning experience (Olson, 1980). Although more recent studies have not examined this trend, internship and practical work experiences are commonplace and a requirement of many academic degree programs. To address the needs of the agricultural 
workforce, cooperative learning programs can provide students with direct, hands-on experience. In effect, this will minimize or eliminate financial limitations to professional development and international experience programs, thereby benefitting academic programs.

\section{International learning programs}

As enhanced globalized communication is fostered by improvements in technology and sharing of information and ideas, it becomes increasingly critical that graduates possess both the necessary communication and cultural skills. The number of employers seeking graduates possessing globalized communication and multicultural competency has grown exponentially within the past two decades (Navarro and Edwards, 2008). As a result of globalized exchange and employment needs, international curricula offered by colleges of agriculture have grown in both popularity and importance (Falk and Kanach, 2006; Ogden, 2007). Examples of international curricula include studyabroad opportunities and courses with a strong emphasis on global issues and culture. Benefits of international curricula include increased global competencies, enhanced worldviews, and internationalization of different cultural concepts (Dooley et al., 2008; Smith et al., 2013; VanDerZanden and Iles, 2013). Despite the wellrecognized benefits of international education, research has demonstrated that agricultural students often have limited international learning experiences and background to meet employment demands (Reimers, 2009; Wingenbach et al., 2006). Factors that limit international learning experiences include financial constraints, undeveloped language skills, lack of cultural knowledge, and lack of available opportunities (Bobbitt and Akers, 2013; Irani et al., 2006; Smith et al., 2013). Despite restrictions on international learning opportunities, students recognize the benefits of such programs for their ability to improve global awareness and enhance communication with members of foreign cultures (Zhai and Scheer, 2004). Research indicates students prefer study-abroad or international learning programs led by faculty from their home institution when compared with study-abroad experiences at a foreign host institution where they are unlikely to have preexisting relationships with faculty (Chang et al., 2013).

\section{An example: University of Florida Cooperative Learning Program}

In an effort to enhance knowledge, share ideas, and improve foreign language and communication skills, students at the University of Florida established a student run horticultural organization (Horticulture Club). To help provide financial support for the organization's events and to support professional development opportunities, student members, and university faculty work cooperatively to cultivate and market horticultural products.

Plant production. The plant production program was initiated in 1998 and has occurred annually since its inception. At the beginning of each fall academic year, 5000 rooted poinsettia (Euphorbia pulcherrima) cuttings are donated from a commercial plant production nursery (Knox Nursery, Winter Garden, FL). About 3500 plants are transplanted into 2 - $\mathrm{L}$ $(0.53 \mathrm{gal})$ containers, whereas the remaining plants are transplanted into a combination of larger or smaller containers ranging in volume from 0.5 to $11 \mathrm{~L}(0.13-2.91 \mathrm{gal})$. Plants are placed in the greenhouse at the University of Florida, Gainesville and cultivated for 17 weeks. Space requirements for production are $\approx 1500 \mathrm{~m}^{2}\left(16,145.9 \mathrm{ft}^{2}\right)$. At the end of the 17-week production period, a multiday plant sale is organized and plants are marketed locally. Although profits have varied, the poinsettia sale earns the club about $\$ 60,000$, annually.

STUDENT Labor. Student club members volunteer to assist in all plant production efforts. At the beginning of fall semester, one student is elected as the "head grower." The student is employed by the university and approved to work $15 \mathrm{~h}$ per week. Funds to support the position are secured from profits from the previous year's plant sale. The head grower is responsible for production tasks, to include pesticide applications and irrigation scheduling, as well as management and scheduling of volunteer student labor.

Financial programmatic SUPPORT. The Horticulture Club uses funds acquired from their efforts to support various academic and professional development opportunities. Through guidance from faculty advisor(s), the Horticulture Club funds travel to professional horticultural trade shows, in-state educational field trips, and national horticultural competitions. In addition to providing financial support to organization members for these opportunities, the student organization also appropriates funding to support expenses associated with an annual international learning experience organized and led by university faculty. The international learning experience includes travel to foreign countries where students visit horticultural production operations, tour farms, and interact with students and faculty at universities and colleges. Collectively, these experiences aid in the development of multicultural competency and help students develop foreign communication skills. Moreover, the international learning experience provides for the development of global perspectives on agricultural production and trade.

Programmatic impacts. Through plant production efforts, Horticulture Club members and faculty have developed a hands-on, cooperative learning program that bolsters connections between theory and practical applications, enhances knowledge of plant productionrelated employment skills, and establishes a sense of responsibility. Moreover, the plant production efforts enhance interpersonal communication skills among Horticulture Club members and afford students with an opportunity that provides a greater comprehension of occupational opportunities. Revenues generated from plant sales are used to fund professional development and international learning programs. This has included travel to professional horticultural meetings, trade shows, production facilities, and horticultural competitions. Such experiences have assisted students in the development of transferrable proficiencies in critical thinking and communication skills, as well as an enhanced understanding of foreign culture 
and international communication. Because academic institutions often have sufficient students, faculty, and physical space, similar cooperative learning programs can be established to enhance student learning and reduce financial limitations that may otherwise restrict professional development and international learning opportunities. Collaborative efforts among academic institutions also could be developed to allow joint learning experiences that would foster peer-to-peer learning opportunities for students at different institutions.

\section{Conclusion}

Diversified job markets and increased global trade require graduates to possess enhanced critical thinking and international communication skills. Employers also desire graduates to possess an extensive knowledge of horticultural theory coupled with hands-on practical experience. Through the establishment of student-based cooperative learning programs, students can master and refine a variety of horticulture skills while raising funds to make professional development and international learning programs more financially feasible.

\section{Literature cited}

Acker, D.G. 1999. Improving the quality of higher education in agriculture globally in the 21 st century: Constraints and opportunities. J. Intl. Agr. Ext. Educ. 6 (2):47-53.

Bobbitt, R. and C. Akers. 2013. Going global: Study abroad intentions of agriculture and natural resource students. North Amer. Colleges Teachers Agr. 57(3a):2127.

Briers, G.E., G.C. Shinn, and A.N. Nguyen. 2010. Through students' eyes: Perceptions and aspirations of college of agriculture and life sciences students regarding international educational experiences. J. Intl. Agr. Ext. Educ. 17(2):6-20.

Campbell, J.R. 1998. Reclaming a lost heritage: Land-grant and other higher education initiatives for the twenty-first century. Michigan State Univ. Press, East Lansing, MI.

Chang, C., O. Pratt, C. Bielecki, M. Balinas, A. McGucken, T. Rutherford, and G.J. Wingenbach. 2013. Agriculture students' interests, preferences, barriers and perceived benefits of international educational experiences. North Amer. Colleges Teachers Agr. 57(3a):97-103.

Dooley, K.E., L.M. Dooley, and G. Carranza. 2008. Beliefs, barriers and benefits of a faculty abroad experience in Mexico. J. Intl. Agr. Ext. Educ. 15(3):29-38.

Falk, R. and N.A. Kanach. 2006. Globalization and study abroad: An illusion of paradox. Frontiers: Interdisciplinary J. Study Abroad 6:155-168.

Irani, T., N.T. Place, and C. Friedel. 2006. Beliefs, attitudes, perceptions and barriers toward international involvement among College of Agriculture and Life Science students. J. Intl. Agr. Ext. Educ. 13(2):27-37.

Karcher, E.L. and N.L. Trottier. 2014. Animal science student perceived benefits of participation in an undergraduate research club. North Amer. Colleges Teachers Agr. 58(1):3-7.

McKeachie, W.J. 1994. Teaching tips: Strategies, research, and theory for college and university teachers. 9th ed. Houghton Mifflin, Boston, MA.

National Research Council. 2009. Transforming agricultural education for a changing world. Natl. Acad. Press, Washington, DC.

Navarro, M. and M.C. Edwards. 2008. Priorities for undergraduate education and the inclusion of internationalized curriculum in college of agriculture:
Interpreting the "comparison dilemma". J. Agr. Educ. 49(4):72-82.

Ogden, A. 2007. The view from the veranda: Understanding today's colonial student. Frontiers: Interdisciplinary J. Study Abroad 15:35-55.

Olson, C.E. 1980. Summary: experiential educational offerings in colleges of agriculture. North Amer. Colleges Teachers Agr. 24(4):8-11.

Reimers, F. 2009. Educating for global competency, p. 183-202. In: J.E. Cohen and M.B. Malin (eds.). International perspectives on the goals of universal basic and secondary education. Routledge, New York, NY.

Rowe, P. 2015. Researchers' reflections on what is missing from work-integrated learning research. Asia-Pac. J. Coop. Educ. 16(2):101-107.

Smith, D.E., M.O. Smith, K.R. Robbins, N.S. Eash, and F.R. Walker. 2013. Traditionally under-represented students' perceptions of a study abroad experience. North Amer. Colleges Teachers Agr. 57(3a):15-20.

Tyler, R.W. 1981. The values of $\mathrm{co}^{-}$ operative education from a pedagogical perspective. J. Coop. Educ. 17(3):48-56.

VanDerZanden, A.M. and J. Iles. 2013. Helping students become global citizens: Successful study abroad programs in the Iowa State University department of horticulture. North Amer. Colleges Teachers Agr. 57(3a):51-55.

Wilson, J.W. and E.H. Lyons. 1961. Work-study college programs. Harper, New York, NY.

Wingenbach, G.J., N. Chmielewski, J. Smith, M. Pina, Jr., and W.T. Hamilton. 2006. Barriers to international experiential participation. J. Intl. Agr. Ext. Educ. 13(3):79-89.

Zhai, L. and S.D. Scheer. 2004. Global perspectives and attitudes toward cultural diversity among summer agriculture students at the Ohio State University. J. Agr. Educ. 45(2):39-51. 